\title{
Habitat conversion and species loss alters the composition of carbon sources to benthic communities
}

\author{
Rebecca J. McLeod ${ }^{1,2, *}$, Stephen R. Wing ${ }^{2}$, Jean P. Davis ${ }^{2}$ \\ ${ }^{1}$ Department of Chemistry, and ${ }^{2}$ Department of Marine Science, University of Otago, PO Box 56, Dunedin 9054, New Zealand
}

\begin{abstract}
Generalist fishes provide an effective measure of the composition of basal carbon source pools fueling benthic communities, by integrating inputs across major consumer groups. In Doubtful Sound, New Zealand, shallow water invertebrate communities differ from those in other areas in Fiordland due to low salinity caused by freshwater output of a hydroelectric power station. To investigate whether the composition of basal carbon sources supporting this benthic community differed from that in unaltered sites, we sampled a generalist wrasse, Notolabrus celidotus, from altered and unaltered habitats throughout Fiordland, and quantified its $\delta^{13} \mathrm{C}, \delta^{15} \mathrm{~N}, \delta^{34} \mathrm{~S}$ and the abundance of its fatty acids. $N$. celidotus from the altered sites in Doubtful Sound had significantly lower $\delta^{13} \mathrm{C}, \delta^{15} \mathrm{~N}$ and $\delta^{34} \mathrm{~S}$ than those collected from similar habitats throughout the Fiordland region, indicating a higher proportion of chemosynthetically fixed organic matter for Doubtful Sound N. celidotus and the invertebrate community upon which they feed. Relatively high abundances of cis-vaccenic acid $(18: 1 \omega 7 \mathrm{c})$ in fish from Doubtful Sound and $\delta^{13} \mathrm{C}$ values that were $-33 \%$ for 18:1 isomers confirmed the incorporation of chemosynthetic bacteria, and indicated that the original source of carbon was forest litter. Despite these differences in carbon supply to $N$. celidotus, analysis of otolith sections revealed no differences in growth rates among sites. The results of this study demonstrate that a shift in invertebrate composition can be indicated by higher order consumers. In Doubtful Sound, decreased abundance of filter-feeding bivalves has reduced the flux of marine derived carbon through the benthic community to higher trophic levels relative to more pristine sites in Fiordland.
\end{abstract}

KEY WORDS: Notolabrus celidotus $\cdot$ Stable isotopes $\cdot$ Fatty acid biomarkers $\cdot$ Compound specific $\delta^{13} \mathrm{C} \cdot$ Food web

Resale or republication not permitted without written consent of the publisher

\section{INTRODUCTION}

Since the seminal paper by Polis \& Hurd (1996) demonstrating subsidies of marine organic matter to desert island food webs, a multitude of studies have highlighted spatial subsidies of nutrients and organic matter across habitat boundaries (e.g. Harding et al. 2004, McLeod \& Wing 2007, Hocking \& Reimchen 2009). Primary tools for identifying these subsidies have included naturally occurring chemical tracers, such as stable isotope ratios of ${ }^{13} \mathrm{C} /{ }^{12} \mathrm{C}$ and ${ }^{15} \mathrm{~N} /{ }^{14} \mathrm{~N}$ (e.g. Rounick et al. 1982, Peterson et al. 1985, Cole et al. 2006). Despite many studies providing strong evidence of incorporation of allochthonous organic matter by individual species (Darnaude et al. 2004, McLeod \& Wing 2009), quantifying the contribution of allochthonous carbon in terms of entire food webs is still difficult. In systems where the primary vectors for uptake of allochthonous material comprise low trophic level species, high temporal and spatial variability in their abundance makes quantification of these vectors challenging. One way to approach questions of the composition of basal carbon sources to whole communities is by sampling generalist feeders that integrate carbon sources by feeding across a wide range of prey (e.g. Vander Zanden \& Vadeboncoeuri 2002, Connolly et al. 2005, McLeod \& Wing 2007). Due to differing rates of tissue turnover, it is likely that stable isotope signa- 
tures of fish muscle tissue integrate carbon source use by a community over months to years (e.g. Guelinckx et al. 2007, Suring \& Wing 2009).

We designed a sampling scheme to test whether anthropogenic modifications to the salinity environment in a New Zealand fjord had altered carbon routing in the benthic community. While the marine and terrestrial environments of the 15 fjords in southern New Zealand, collectively known as Fiordland, remain relatively pristine, Doubtful Sound receives an average of $450 \mathrm{~m}^{3} \mathrm{~s}^{-1}$ of freshwater outflow from the Manapouri Hydroelectric Power Station. The resulting persistent shallow low salinity layer (Gibbs et al. 2000) has led to a reduction in the abundance of filter-feeding invertebrates including infaunal clams (Tallis et al. 2004, Rutger \& Wing 2006, McLeod \& Wing 2008) and mussels (Jack et al. 2009). The decreased biomass of filterfeeding bivalves could dramatically reduce the capture of particulate carbon (from both phytoplankton and eroded macroalgae) from the water column, with a concomitant reduction in the flux of marine-derived organic matter into the benthic food web (McLeod \& Wing 2008). This setting of an altered habitat and its associated community, and multiple unaltered habitats, provides an opportunity to test for differences in carbon source pools that are supporting benthic communities.

Recent studies in Doubtful Sound have demonstrated that primary consumers (e.g. the grazing sea urchin Evechinus chloroticus and the detritivorous sea cucumber Australostichopus mollis) use increased proportions of recycled carbon and forest litter with proximity to the inner reaches of the fjord (Wing et al. 2008). This pattern is also reflected in the diets of blue cod Parapercis colias (Rodgers \& Wing 2008) and red rock lobster Jasus edwardsii (Jack et al. 2009), which commonly prey upon Solemya parkinsonii (a clam that hosts chemoautotrophic bacteria) in these regions. For $J$. edwardsii, the loss of preferred bivalve prey species such as Mytilus edulis galloprovincialis, which has strong links to the productive marine algal carbon pool, has resulted in a shift in diet to the less abundant $S$. parkinsonii, which recycle carbon from forest litter. This shift in diet and carbon source pool coincides with a marked reduction in the abundance of $J$. edwardsii in these altered habitats. These patterns demonstrate the dramatic implications of shifts in species composition and routing of carbon source pools on the functioning of marine food webs (Jack et al. 2009).

In the present study, we used a common and abundant wrasse, Notolabrus celidotus, to indicate the relative incorporation of carbon sources by the estuarine macroinvertebrate community. Stable isotope ratios of carbon, nitrogen and sulfur were employed to test for differences in total carbon flux to the communities inhabiting anthropogenically altered and pristine habitats. Determination of $\delta^{13} \mathrm{C}$ of specific fatty acid compounds was employed as an independent discriminator of basal carbon sources among these sites. We then tested whether a shift in composition of carbon sources to the base of the food web has had any detectable effect on age at size of $N$. celidotus.

\section{MATERIALS AND METHODS}

Study sites. Throughout Fiordland, deposition of alluvial sediments at the mouths of rivers forms deltaic soft sediment habitats, which are most extensive at the head of each fjord. The primary study sites are distributed on isolated soft sediment river deltas between which are expanses of steep rock wall habitat. The sediment has a high organic content (up to $83 \%$; Pickrill 1980), consisting predominantly of forest litter (Pickrill 1987, McLeod \& Wing 2009). The macroinfaunal communities associated with these deltas are diverse, including a range of molluscs, crustaceans, annelids and echinoderms (Rutger \& Wing 2006, McLeod \& Wing 2008). The majority of taxa obtain the bulk of their nutrition from marine algae; however, 4 species that collectively comprise $\sim 30 \%$ of the community biomass obtain a significant amount of carbon from forest litter via microbial pathways (McLeod \& Wing 2009). Of particular note is the clam Solemya parkinsonii, which obtains its energy solely from endosymbiotic chemoautotrophic bacteria (McLeod \& Wing 2007). The inner reaches of Doubtful Sound (Hall Arm, Deep Cove) has depressed abundances of the infaunal bivalves Austrovenus stutchburyi and Paphies australis owing to large inputs of freshwater from the Manapouri Hydroelectric Power Station (McLeod \& Wing 2008). In contrast, the biomass of these species in neighboring Bradshaw Sound (a fjord that is not directly affected by the power station) is $29 \times$ larger than in inner Doubtful Sound ( 215 vs. $\sim 7$ fresh weight). These bivalve species are common throughout the wider Fiordland region (R. J. McLeod pers. obs.). Shallow subtidal macroalgal assemblages are dominated by Ulva spp., with Gracilaria chilensis, Hormosira banksii and Pilayella littoralis occurring intertidally in the inner reaches of most fjords (Nelson et al. 2002). Discrete beds of seagrass (Zostera capricorni) are present near river deltas throughout Fiordland, but are not detected from the inner reaches of Doubtful Sound (R. J. McLeod unpubl. data).

Sample collection and preparation. Notolabrus celidotus were collected between July 2004 and February 2007 using baited hand lines, and by a diver using a sling-spear. A nested sampling scheme was employed, with fish being collected across multiple seasons from altered inner Doubtful Sound sites (Hall Arm, Deep 
Cove), at unaltered sites within the Doubtful-Bradshaw Sound complex (Bradshaw Sound sites: Gaer Arm, Precipice Cove, Rum Cove) and from outer Doubtful Sound sites (Bauza Island, Causet Cove) (Fig. 1). N. celidotus were collected from sites throughout the wider Fiordland region in 2005 (see Fig. 1). Samples consisted of 5 to 10 ind. site ${ }^{-1}$ and sampling event $^{-1}$. All sites are situated on relatively sheltered soft sediment river deltas, with the exception of Bauza Island, which is a rock wall site in the outer reaches of Doubtful Sound. Whole fish were stored frozen $\left(-20^{\circ} \mathrm{C}\right)$ and transported to the Portobello Marine Laboratory where a subsample of boneless muscle tissue was dissected from the dorsolateral region of each individual and dried at $60^{\circ} \mathrm{C}$ to a constant weight.

Stable isotope analysis. Dried samples of muscle tissue were homogenized using a mortar and pestle, and packed into individual foil capsules for analysis of $\delta^{15} \mathrm{~N}$ and $\delta^{13} \mathrm{C}(\sim 1 \mathrm{mg})$. Analyses of $\delta^{15} \mathrm{~N}$ and $\delta^{13} \mathrm{C}$ were performed by Iso-trace New Zealand Ltd. (Dunedin). Samples were analyzed on a stable isotope mass spectrometer (Europa 20-20 update) that was interfaced to an elemental analyzer (Carlo Erba NA1500) in continuous flow mode (precision: $0.2 \%$ for $\delta^{13} \mathrm{C}, 0.3 \%$ or $\delta^{15} \mathrm{~N}$ ). Analysis was calibrated using an EDTA laboratory standard reference (Elemental Microanalysis) and standardized against international standards (IAEACH-6 for carbon, IAEAN1 and IAEAN2 for nitrogen).

A subset of samples of Notolabrus celidotus from Deep Cove, Gaer Arm and Dusky Sound ( $\mathrm{n}=4$ at each site) was analyzed for $\delta^{34} \mathrm{~S}$. Subsample mass for $\delta^{34} \mathrm{~S}$ analysis was adjusted to obtain $30 \mu \mathrm{g}$ sulfur, and subsamples were sent to the Iso-Analytical Laboratory (Crewe, UK) for analysis. All stable isotope results are expressed in the standard delta notation (e.g. Peterson \& Howarth 1987), where e.g. $\delta^{13} \mathrm{C}=\left[\left(\mathrm{R}_{\mathrm{smpl}} / \mathrm{R}_{\text {std }}\right)-1\right] \times$ 1000 , where $R_{\text {smpl }}={ }^{13} \mathrm{C} /{ }^{12} \mathrm{C}$ of the sample and $R_{\text {std }}=$ ${ }^{13} \mathrm{C} /{ }^{12} \mathrm{C}$ of Peedee belemnite limestone. The primary standards for $\delta^{15} \mathrm{~N}$ and $\delta^{34} \mathrm{~S}$ were atmospheric nitrogen and the Diablo Canyon meteorite respectively.

Statistical analyses of $\delta^{15} \mathrm{~N}, \delta^{13} \mathrm{C}$ and $\delta^{34} \mathrm{~S}$. Univariate statistical tests were performed using a 2-phase approach to test for differences in $\delta^{15} \mathrm{~N}, \delta^{13} \mathrm{C}$ and $\delta^{34} \mathrm{~S}$ values of Notolabrus celidotus throughout Fiordland. The first hypothesis tested was that $\delta^{15} \mathrm{~N}, \delta^{13} \mathrm{C}$ and $\delta^{34} \mathrm{~S}$ of $N$. celidotus are the same between altered (inner Doubtful Sound) and unaltered sites (all other sites). The second hypothesis tested was that $\delta^{15} \mathrm{~N}, \delta^{13} \mathrm{C}$ and $\delta^{34} \mathrm{~S}$ of $N$. celidotus from all unaltered sites (by fjord) are the same. Data on $\delta^{15} \mathrm{~N}, \delta^{13} \mathrm{C}$ and $\delta^{34} \mathrm{~S}$ were transformed to meet the assumptions of ANOVA. If these assumptions were not met, a Kruskal-Wallis test was performed. To test for temporal variability in values of $\delta^{13} \mathrm{C}$ and $\delta^{15} \mathrm{~N}$ of $N$. celidotus at Deep Cove, parallel 1 -way ANOVAs were performed on raw data (5 sampling events between Jul 2004 and Oct 2006), with sampling event as a factor. To test for temporal variability in values of $\delta^{13} \mathrm{C}$ and $\delta^{15} \mathrm{~N}$ of $N$. celidotus at Hall Arm, parallel Kruskal-Wallis tests were performed on raw data (3 sampling events between Jul 2004 and Oct 2006), with sampling event as a factor. All statistics were performed using SPSS 17.0 (2009).
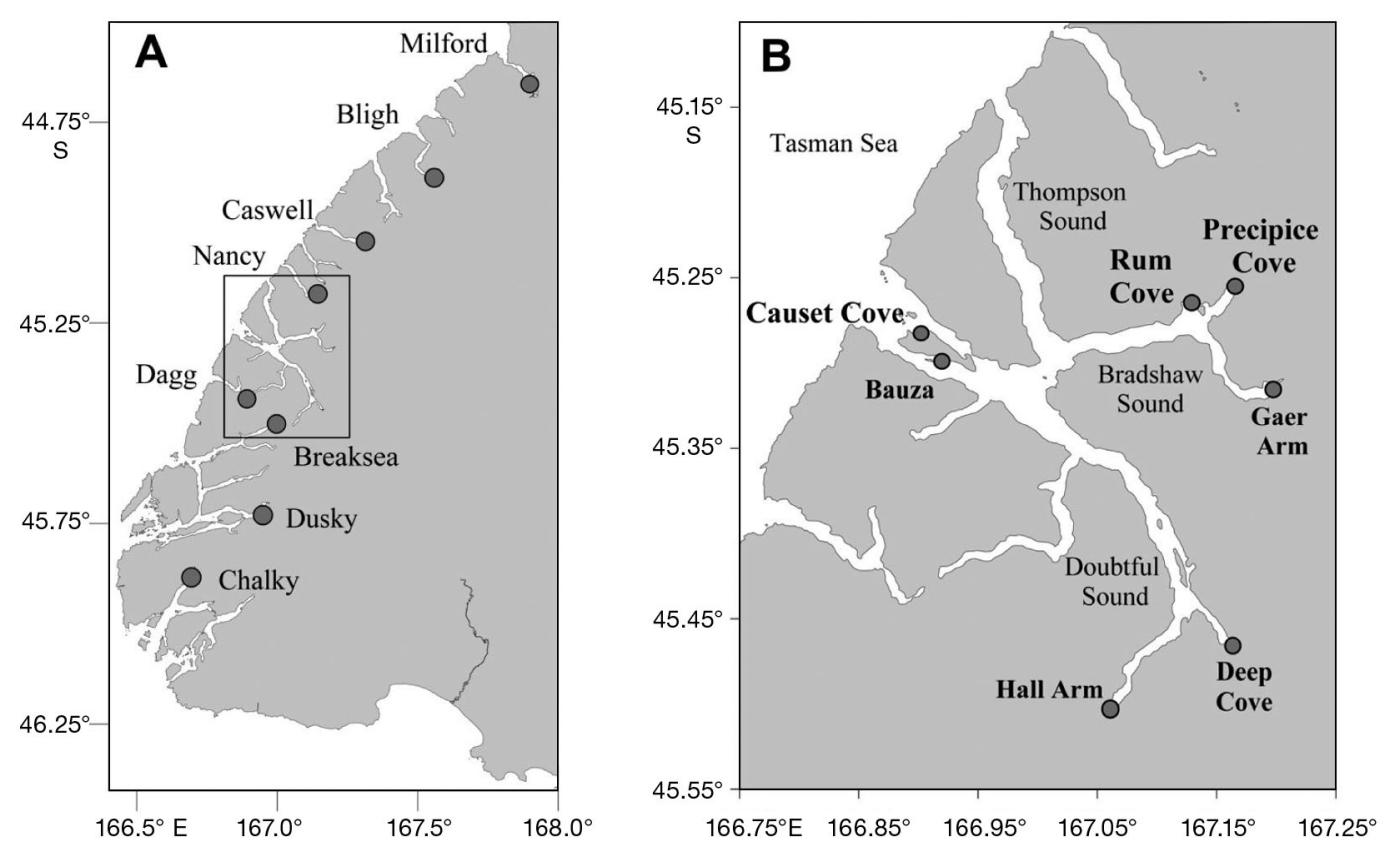

Fig. 1. (A) Notolabrus celidotus collection sites in Fiordland, New Zealand (November 2005). (B) N. celidotus collection sites in Doubtful and Bradshaw Sounds (2004 to 2006) 
Mean values and SDs of $\delta^{13} \mathrm{C}$ and $\delta^{15} \mathrm{~N}$ for Notolabrus celidotus from altered and unaltered sites and of potential sources of organic matter (from Jack et al. 2009) were entered into the isotopic mixing model IsoError (Phillips \& Gregg 2001a,b). The model estimated the average organic matter source contributions to fish from each group of sites. The model was then rerun using values of $\delta^{13} \mathrm{C}$ and $\delta^{34} \mathrm{~S}$, with an average value of $\delta^{13} \mathrm{C}$ for 'marine algae' being weighted from the outputs of the first model.

Fatty acid characterization and $\delta^{13} \mathrm{C}$ determination. Lipids were extracted from $\sim 20 \mathrm{mg}$ subsamples of dried homogenized samples of Notolabrus celidotus (inner Doubtful Sound $n=8$, Bradshaw Sound $n=7$, Dusky and Chalky Sounds $\mathrm{n}=8$ ) using a modified Bligh \& Dyer (1959) procedure as described previously (McLeod \& Wing 2009). The lipid fraction was treated with analytical grade sulfuric acid in methanol solution and underwent acid-catalyzed transesterification at $80^{\circ} \mathrm{C}$ for $3 \mathrm{~h}$. Fatty acid methyl esters (FAMEs) were extracted in hexane/water, with the hexane layer being removed and stored at $8^{\circ} \mathrm{C}$.

Fatty acid (FA) composition was determined by gas chromatography (GC) on a GC System (6850N Network, Agilent Technologies) that was equipped with a flame ionization detector. FAMEs were separated on a capillary column (Equity-1; $15 \mathrm{~m} \times 0.1 \mathrm{~mm}$ i.d., $0.1 \mu \mathrm{m}$ film) (Sigma-Aldrich/Supelco). The column oven temperature was held at $120^{\circ} \mathrm{C}$ for $3 \mathrm{~min}$, ramped to $270^{\circ} \mathrm{C}$ at $10^{\circ} \mathrm{C}$ $\mathrm{min}^{-1}$, and then ramped to $290^{\circ} \mathrm{C}$ at $5^{\circ} \mathrm{C} \mathrm{min}^{-1}$. FA peaks were identified by matching retention times with those of commercially available FAME standards (NuCheck Prep and Sigma). Peak identities were then confirmed by mass spectrometry. Peak areas were calculated and reported as percentage of total FA. FA notation describes the carbon chain length, followed by a colon and the number of double bonds. The position of the first double bond is specified from the methyl end $(\omega)$, with all subsequent bonds being methylene-interrupted. Similarity in FA composition of Notolabrus celidotus among fjords (inner Doubtful, Bradshaw, Chalky, and Dagg Sounds) was explored using Multidimensional Scaling Analysis (MDS; PRIMER v.6 and PERMANOVA+ v.1, Primer-E 2009) based on Euclidean distance measures. Data were selectively square root transformed to improve the distribution of residuals.

For a subset of samples (inner Doubtful Sound $\mathrm{n}=3$, Bradshaw Sound $n=4$, Chalky Sound $n=4$ ), the $\delta^{13} C$ composition of methyl ester derivatives was measured using a trace gas chromatograph (Thermo) that was coupled to an isotope ratio mass spectrometer (Mat Delta S, Finnigan). Each sample $(0.5 \mu \mathrm{l})$ was injected directly onto a column (HP-5; $50 \mathrm{~m} \times 0.32 \mathrm{~mm}$ i.d., $0.2 \mu \mathrm{m}$ film) (Agilent). Compounds were combusted at $940^{\circ} \mathrm{C}$ to form $\mathrm{CO}_{2}$ inside a micro combustion furnace. Combustion was assisted by the presence of $\mathrm{CuO}, \mathrm{Pt}$ and $\mathrm{NiO}$. Helium was used as the carrier gas and flowed at $2 \mathrm{ml} \mathrm{min}^{-1}$. The initial oven temperature of $40^{\circ} \mathrm{C}$ was maintained for $1 \mathrm{~min}$, ramped to $120^{\circ} \mathrm{C}$ at $30^{\circ} \mathrm{C} \mathrm{min}^{-1}$, and then ramped to $315^{\circ} \mathrm{C}$ at $4^{\circ} \mathrm{C} \mathrm{min}^{-1}$ and maintained for $15 \mathrm{~min}$. The stability of analysis was monitored using $\mathrm{CO}_{2}$ gas pulses at the beginning and end of each sample analysis. Measured isotope ratios were normalized to the international scale using laboratory standard FAMEs. A precision of $\pm 0.2 \%$ was achieved. FA peaks were identified by retention time matching as described previously. Mass balance equations accounted for methanol that was added during methylation.

Age at size analysis. Age at size analysis was performed on individuals from all sampling sites $(\mathrm{n}=130)$. Each fish was weighed (blotted fresh weight) and measured for total length. Sagittal otoliths were removed and air dried, permanently fixed on glass slides, and wet sanded flat using 600 and 1200 grit sandpaper. Otoliths were then viewed under low power using a compound light microscope. Otoliths were given a readability score of $1-5$ (easy to difficult) and those that were rated 5 were excluded from analysis. Age estimates were made independently by 2 readers. The mean $\mathrm{CV}$ was calculated to estimate age precision for a given fish. The mean $\mathrm{CV}$ between readers during otolith aging was $<7.6 \%$, which was accepted as a valid analysis based on previous studies (Campana 2001). Mean length and weight of fish for each age class comprising $\geq 9$ replicates $(3,4,5$ and 6 yr olds) were compared between inner Doubtful Sound and all other sampling sites using 1-way ANOVA.

\section{RESULTS}

\section{Values of $\delta^{15} \mathrm{~N}$, $\delta^{13} \mathrm{C}$ and $\delta^{34} \mathrm{~S}$ in Notolabrus celidotus}

Values of $\delta^{15} \mathrm{~N}$ and $\delta^{13} \mathrm{C}$ varied considerably among individual Notolabrus celidotus throughout Fiordland (range: $\delta^{15} \mathrm{~N}=2.7$ to $13.6 \%$, $\delta^{13} \mathrm{C}=-28.5$ to $-15.3 \%$ ), although there was relatively little variation among individuals within most sites. $N$. celidotus from altered sites (Deep Cove, Hall Arm) were significantly more depleted in ${ }^{15} \mathrm{~N}\left(\delta^{15} \mathrm{~N}: \chi^{2}=52.327, \mathrm{df}=1, \mathrm{p}<0.001\right)$ and ${ }^{13} \mathrm{C}\left(\delta^{13} \mathrm{C}: F_{1,120}=99.230, \mathrm{p}<0.001\right)$ than $N$. celidotus from all other sites in Fiordland (Fig. 2). There was no significant difference in values of $\delta^{15} \mathrm{~N}$ or $\delta^{13} \mathrm{C}$ among unaltered sites $\left(\delta^{15} \mathrm{~N}: \chi^{2}=14.522, \mathrm{df}=8, \mathrm{p}=0.069 ; \delta^{13} \mathrm{C}\right.$ : $\left.F_{8,72}=0.660, \mathrm{p}=0.725\right)$. Values of $\delta^{34} \mathrm{~S}$ were significantly lower for fish from Deep Cove than for those from Bradshaw and Dusky combined $\left(\delta^{34} \mathrm{~S}: F_{1,11}=\right.$ $6.665, p=0.027$ ) (Fig. 3), and values for fish from Bradshaw were significantly lower than for those from Dusky $\left(\delta^{34} \mathrm{~S}: F_{1,7}=9.202, \mathrm{p}=0.023\right)$. 

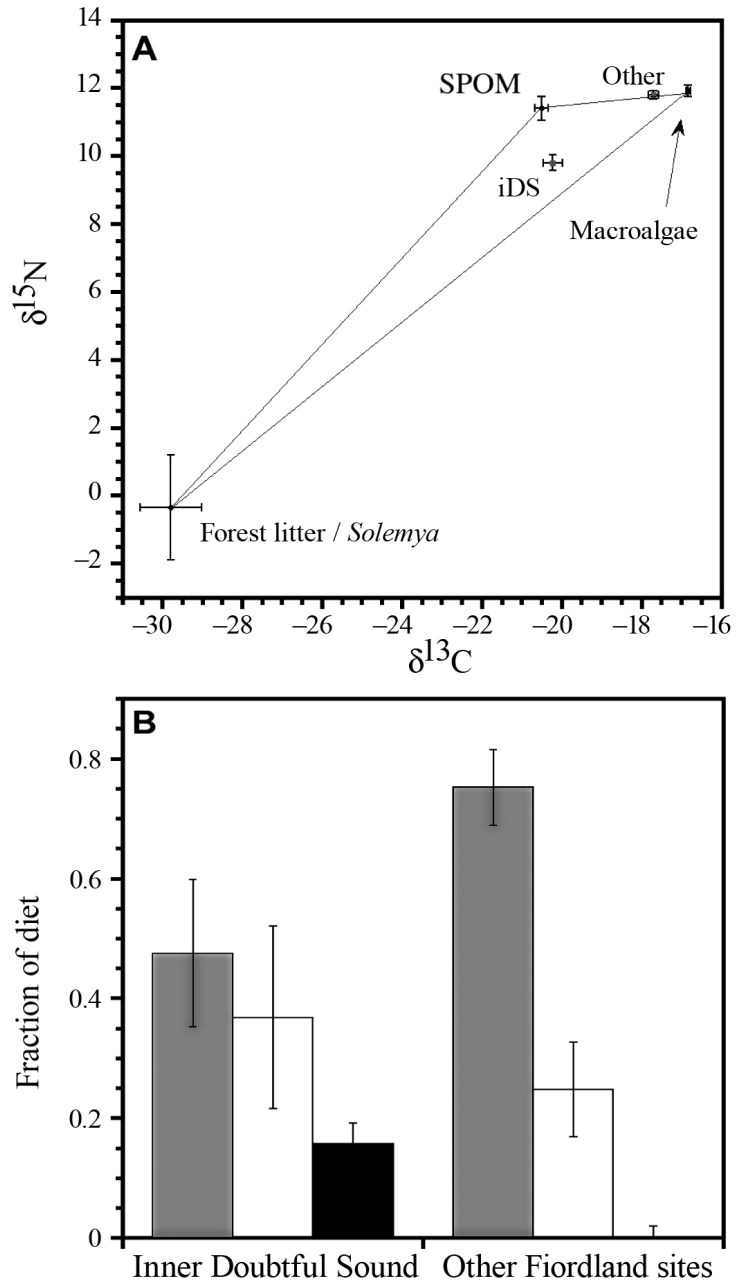

Fig. 2. Notolabrus celidotus. (A) $\delta^{13} \mathrm{C}$ and $\delta^{15} \mathrm{~N}$ (mean $\pm 1 \mathrm{SE}$; $\%$ ) values of individuals collected from sites in the inner reaches of Doubtful Sound (iDS), and from all other sites throughout Fiordland (other) relative to values of potential food sources. Values of food sources have been adjusted for trophic fractionation $\left(\delta^{13} \mathrm{C}+0.4, \delta^{15} \mathrm{~N}+2.4\right.$; McCutchan et al. 2003); (B) estimates (mean $\pm 1 \mathrm{SE}$ ) of the fraction of macroalgae (dark grey), suspended particulate organic matter (SPOM; white) and forest litter/chemosynthetically fixed carbon (black) contributing to $N$. celidotus diet for both site groupings

\section{Temporal variation in Notolabrus celidotus $\delta^{15} \mathrm{~N}$ and $\delta^{13} \mathrm{C}$}

Repeated sampling events of Notolabrus celidotus from Deep Cove showed no significant variability in $\delta^{15} \mathrm{~N}\left(F_{2,32}=1.192, \mathrm{p}=0.3362\right)$ or $\delta^{13} \mathrm{C}\left(F_{2,32}=2.190, \mathrm{p}=\right.$ 0.0960). Values of $\delta^{15} \mathrm{~N}$ and $\delta^{13} \mathrm{C}$ of $N$. celidotus from Hall Arm increased slightly over time; however, the mean values of $\delta^{15} \mathrm{~N}$ and $\delta^{13} \mathrm{C}$ were consistently more depleted in ${ }^{15} \mathrm{~N}$ and ${ }^{13} \mathrm{C}$ at this site than at other sites throughout the wider Fiordland region $\left(\delta^{15} \mathrm{~N}: \chi^{2}=\right.$ 8.249, $p=0.0162 ; \delta^{13} \mathrm{C}: \chi^{2}=9.081, \mathrm{p}=0.0107$ ).
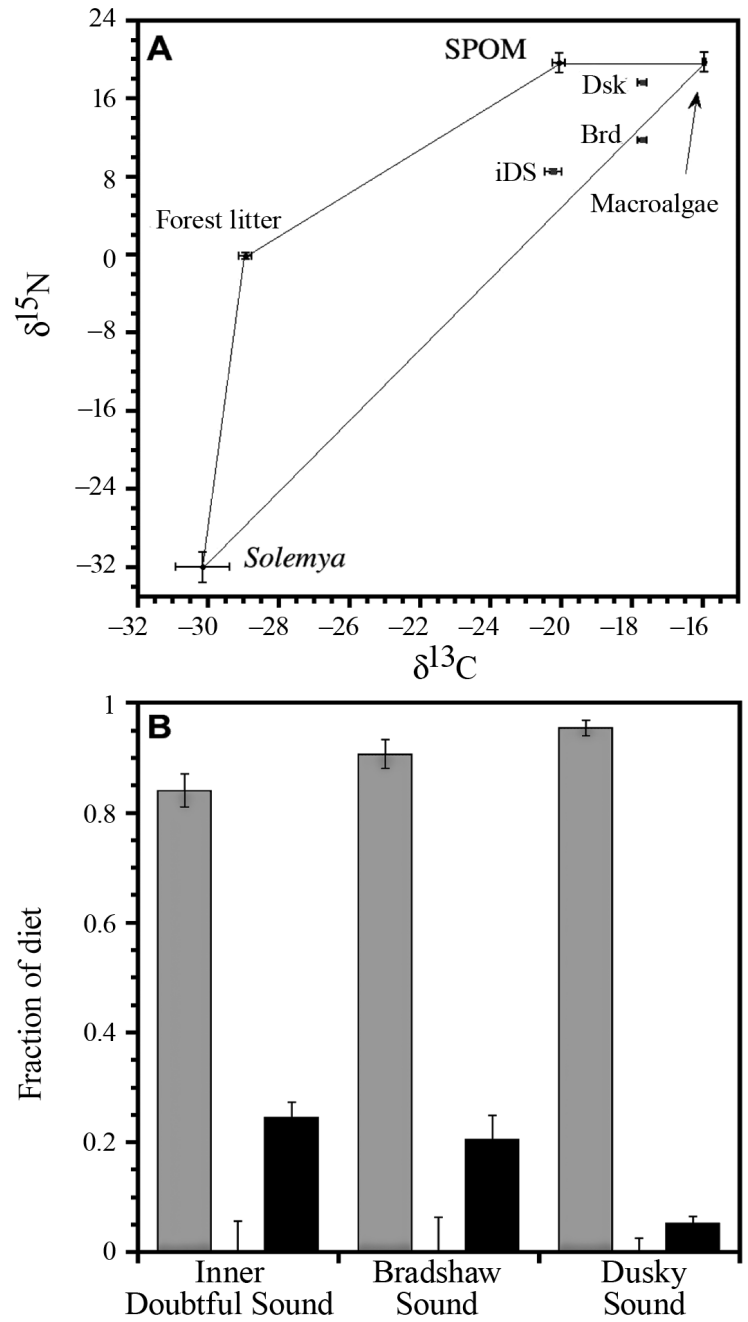

Fig. 3. Notolabrus celidotus. (A) $\delta^{13} \mathrm{C}$ and $\delta^{34} \mathrm{~S}$ (mean $\pm 1 \mathrm{SE}$; $\%$ ) values of individuals collected from sites in the inner reaches of Doubtful Sound (iDS), Bradshaw Sound (Brd) and sites from Dusky Sound (Dsk) relative to values of potential food sources. Values of food sources have been adjusted for trophic fractionation $\left(\delta^{13} \mathrm{C}+0.4, \delta^{34} \mathrm{~S}+0.4\right.$; (McCutchan et al. 2003); (B) estimates (mean $\pm 1 \mathrm{SE}$ ) of the fraction of marine algae (macroalgae $+\mathrm{SPOM}_{i}$ grey), forest litter (white) and chemosynthetically fixed carbon (black) contributing to $N$. celidotus diet for each site grouping

\section{Mixing models}

Using values of $\delta^{15} \mathrm{~N}$ and $\delta^{13} \mathrm{C}$, the model IsoError estimated that Notolabrus celidotus from inner Doubtful Sound obtained an average of $15.7 \%$ (95\% CI: 8.4 to $23.0 \%$ ) of organic matter from forest litter and/or chemosynthetically fixed organic matter (Fig. 2b). In contrast, values of $\delta^{15} \mathrm{~N}$ and $\delta^{13} \mathrm{C}$ for $N$. celidotus from throughout all other study sites in Fiordland indicated that $0 \%$ (95\% CI: 0 to $3.7 \%)$ of organic matter came from this source. At both inner Doubtful Sound and all other sites, the main inputs were marine algae, and 
macroalgal production supported more secondary production than did pelagic production at most unaltered sites. While values of $\delta^{15} \mathrm{~N}$ and $\delta^{13} \mathrm{C}$ for forest litter and chemosynthetically fixed carbon (Solemya parkinsonii) were not discrete, these sources were well-separated using values of $\delta^{34} \mathrm{~S}$ (Fig. 3a). Using values of $\delta^{34} \mathrm{~S}$ and $\delta^{13} \mathrm{C}$, the mixing model estimated that forest litter was not used directly by $N$. celidotus (and its prey), but chemosynthetically derived organic matter was a most likely dietary component (Fig. 3b). Chemoautotrophic organic matter was estimated to comprise $24.4 \pm$ 2.9 (SE), $20.4 \pm 4.5$, and $5.1 \pm 1.3 \%$ of the diet of N. celidotus from inner Doubtful Sound, Bradshaw Sound, and wider Fiordland sites respectively.

\section{Fatty acid biomarkers and $\delta^{13} \mathrm{C}$ of individual fatty acids}

The most abundant FA compounds of Notolabrus celidotus were the saturated FA 16:0 and the polyunsat-

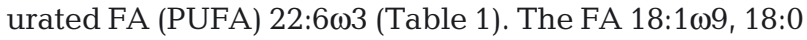
and 20:5 $\omega 3$ were present in moderate abundances. All other FA compounds each comprised $\leq 6 \%$ of the total FA. Low abundances of higher plant and seagrass biomarkers $\left(\mathrm{C}_{24} \mathrm{FA}, 18: 2 \omega 6+18: 3 \omega 3\right)$ indicated that these sources did not provide a significant direct source of nutrition. At all sites, there were high abundances of $\omega 3$ and $\omega 6$ PUFA (particularly 22:6 $\omega 3,20: 5 \omega 3,22: 5 \omega 3$ and

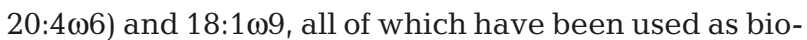

Table 1. Notolabrus celidotus. Fatty acid composition (\% of total fatty acids) and $\delta^{13} \mathrm{C}(\%)$ of fatty acids for samples from Fiordland. 'Wider Fiordland' is represented by samples from Chalky Sound. Where baseline separation of fatty acid components was not achieved, values of $\delta^{13} \mathrm{C}$ are provided for multiple fatty acids. $i$ : iso, $a$ : anteiso, c: cis, t: trans, MUFA: monounsaturated fatty acids, PUFA: polyunsaturated fatty acids, SFA: saturated fatty acids. Where applicable, values are mean $\pm \mathrm{SE}$

\begin{tabular}{|c|c|c|c|c|c|c|}
\hline \multirow{2}{*}{ Component } & \multicolumn{3}{|c|}{$\%$ of total fatty acids } & \multicolumn{3}{|c|}{$-\delta^{13} \mathrm{C}$ of fatty acid component } \\
\hline & $\begin{array}{l}\text { Inner Doubtful } \\
\quad(\mathrm{n}=8)\end{array}$ & $\begin{array}{l}\text { Bradshaw } \\
\quad(n=7)\end{array}$ & $\begin{array}{l}\text { Wider Fiordland } \\
\qquad(\mathrm{n}=8)\end{array}$ & $\begin{array}{l}\text { Inner Doubtful } \\
\quad(\mathrm{n}=3)\end{array}$ & $\begin{array}{l}\text { Bradshaw } \\
(\mathrm{n}=4)\end{array}$ & $\begin{array}{l}\text { Wider Fiordland } \\
\qquad(\mathrm{n}=4)\end{array}$ \\
\hline 14:0 & $2.73 \pm 1.17$ & $3.13 \pm 0.90$ & $4.16 \pm 1.31$ & -31.0 & -23.8 & -23.8 \\
\hline i15:0 & $0.19 \pm 0.04$ & $0.32 \pm 0.07$ & $0.14 \pm 0.04$ & & & \\
\hline a15:0 & $0.07 \pm 0.02$ & $0.14 \pm 0.04$ & $0.02 \pm 0.01$ & & & \\
\hline $15: 0$ & $0.47 \pm 0.05$ & $0.60 \pm 0.06$ & $0.45 \pm 0.03$ & & & \\
\hline $16: 1 \omega 9 \mathrm{c}$ & $0.25 \pm 0.04$ & $0.25 \pm 0.03$ & $0.23 \pm 0.11$ & & & \\
\hline $16: 1 \omega 7 \mathrm{C}$ & $2.62 \pm 0.56$ & $2.71 \pm 0.52$ & $1.71 \pm 0.40$ & -31.9 & -24.6 & -22.1 \\
\hline $16: 1 \omega 5 c$ & $0.43 \pm 0.06$ & $0.36 \pm 0.07$ & $0.14 \pm 0.02$ & & & \\
\hline $16: 0$ & $20.15 \pm 0.61$ & $22.65 \pm 0.73$ & $27.45 \pm 2.21$ & $-31.5 \pm 0.5$ & $-25.8 \pm 0.6$ & $-24.3 \pm 0.6$ \\
\hline Br17:1 & $0.07 \pm 0.03$ & $0.08 \pm 0.02$ & $0.29 \pm 0.11$ & & & \\
\hline$i 17: 0$ & $0.67 \pm 0.09$ & $0.68 \pm 0.11$ & $0.41 \pm 0.03$ & -27.7 & -26.7 & \\
\hline $17: 1 \omega 8 \mathrm{c}+i 17: 0$ & $0.81 \pm 0.07$ & $0.83 \pm 0.13$ & $0.36 \pm 0.02$ & & & \\
\hline $17: 0$ & $0.75 \pm 0.09$ & $0.75 \pm 0.10$ & $0.58 \pm 0.03$ & -32.3 & -28.9 & \\
\hline $18: 2 \omega 6$ & $1.98 \pm 0.20$ & $1.63 \pm 0.12$ & $0.86 \pm 0.08$ & & & \\
\hline $18: 3 \omega 3+i 18: 0$ & $0.77 \pm 0.16$ & $0.77 \pm 0.17$ & $0.25 \pm 0.06$ & & & \\
\hline $18: 1 \omega 9 \mathrm{c}$ & $9.26 \pm 1.24$ & $9.54 \pm 1.61$ & $6.54 \pm 1.32$ & $-33.0 \pm 0.3$ & $-27.1 \pm 0.7$ & $-30.6 \pm 0.7$ \\
\hline $18: 1 \omega 7 \mathrm{C}$ & $5.01 \pm 0.52$ & $4.70 \pm 0.61$ & $2.79 \pm 0.29$ & & & \\
\hline $18: 1 \omega 5 c$ & $0.26 \pm 0.03$ & $0.21 \pm 0.03$ & $0.12 \pm 0.03$ & & & \\
\hline $18: 0$ & $7.75 \pm 0.49$ & $7.36 \pm 0.32$ & $8.61 \pm 0.54$ & $-32.0 \pm 1.0$ & $-27.3 \pm 0.9$ & $-24.9 \pm 0.8$ \\
\hline $20: 4 \omega 6$ & $4.56 \pm 0.19$ & $2.91 \pm 0.17$ & $2.51 \pm 0.35$ & & & \\
\hline $20: 5 \omega 3$ & $6.81 \pm 0.39$ & $6.73 \pm 0.36$ & $6.61 \pm 0.26$ & & & \\
\hline C20 MUFA & $0.11 \pm 0.05$ & $0.22 \pm 0.03$ & $0.16 \pm 0.06$ & & & \\
\hline $20: 2 \omega 6$ & $0.38 \pm 0.03$ & $0.39 \pm 0.04$ & $0.21 \pm 0.03$ & & & \\
\hline $20: 1 \omega 9+11 c$ & $0.99 \pm 0.16$ & $0.97 \pm 0.21$ & $0.74 \pm 0.11$ & & & \\
\hline $20: 1 \omega 7 c$ & $0.40 \pm 0.06$ & $0.55 \pm 0.12$ & $0.23 \pm 0.03$ & & & \\
\hline 20:0 & $0.15 \pm 0.02$ & $0.18 \pm 0.02$ & $0.15 \pm 0.01$ & & & \\
\hline $22: 5 \omega 6$ & $1.09 \pm 0.39$ & $0.37 \pm 0.05$ & $0.31 \pm 0.04$ & & & \\
\hline $22: 6 \omega 3$ & $20.90 \pm 2.62$ & $20.90 \pm 2.78$ & $26.43 \pm 2.72$ & -35.4 & $-29.7 \pm 0.6$ & $-27.2 \pm 0.1$ \\
\hline $22: 4 \omega 6$ & $0.82 \pm 0.15$ & $0.77 \pm 0.17$ & $0.70 \pm 0.10$ & & & \\
\hline $22: 5 \omega 3$ & $2.44 \pm 0.36$ & $2.21 \pm 0.32$ & $1.19 \pm 0.29$ & & & \\
\hline C22 PUFA1 & $0.11 \pm 0.05$ & $0.08 \pm 0.03$ & $0.05 \pm 0.02$ & & & \\
\hline C22 PUFA2 & $0.06 \pm 0.04$ & $0.18 \pm 0.08$ & $0.00 \pm 0.00$ & & & \\
\hline $22: 0$ & $5.77 \pm 0.61$ & $5.59 \pm 0.71$ & $4.30 \pm 1.28$ & & & \\
\hline $24: 1$ & $1.03 \pm 0.11$ & $1.05 \pm 0.13$ & $1.18 \pm 0.12$ & & & \\
\hline $24: 0$ & $0.15 \pm 0.03$ & $0.18 \pm 0.03$ & $0.15 \pm 0.01$ & & & \\
\hline$\Sigma \mathrm{C}_{15}+\mathrm{C}_{17}$ & $3.03 \pm 0.41$ & $3.40 \pm 0.54$ & $2.25 \pm 0.27$ & & & \\
\hline$\Sigma \omega 3$ & $30.92 \pm 3.54$ & $30.62 \pm 3.63$ & $34.48 \pm 3.33$ & & & \\
\hline$\Sigma \omega 6$ & $8.84 \pm 0.96$ & $6.08 \pm 0.55$ & $4.58 \pm 0.61$ & & & \\
\hline$\Sigma$ SFA & $37.91 \pm 3.07$ & $40.44 \pm 2.86$ & $45.83 \pm 5.43$ & & & \\
\hline$\Sigma$ MUFA & $21.05 \pm 2.87$ & $21.17 \pm 3.46$ & $14.03 \pm 2.45$ & & & \\
\hline$\Sigma$ PUFA & $39.92 \pm 4.59$ & $36.97 \pm 4.29$ & $39.11 \pm 3.95$ & & & \\
\hline
\end{tabular}


markers for marine algae in previous studies (Johns et al. 1979, Kharlamenko et al. 2001). Cis-vaccenic acid $(18: 1 \omega 7 \mathrm{C})$, which is a biomarker for bacteria, and monounsaturated FA in general, were present in higher abundances in fish from inner Doubtful and Bradshaw Sounds, than in those from the other sites. $\mathrm{C}_{15}$ and $\mathrm{C}_{17}$ FA comprised $>3 \%$ of total FA at Doubtful and Bradshaw Sound sites, and $2.2 \%$ at other sites. MDS analysis of FA abundance data did not reveal any clear patterns for the FA composition of $N$. celidotus muscle tissue among sites or fjords.

$\delta^{13} \mathrm{C}$ values of FA were typically lower for Notolabrus celidotus from inner Doubtful Sound than for those from Bradshaw and Chalky Sounds (see Table 1). The largest discrepancy in $\delta^{13} \mathrm{C}$ between fish from inner Doubtful Sound and those from other sites occurred with shorter chain FA, which are precursors for longer chain FA in the biosynthetic pathway (Dalsgaard et al. 2003). The lowest mean values of $\delta^{13} \mathrm{C}$ were for the $\mathrm{C} 22$

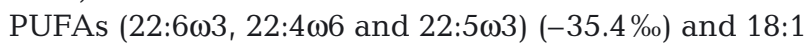
$(-33.0 \%$ ) from inner Doubtful Sound.

\section{Length and weight at age}

Sample sizes $\geq 9$ allowed for robust statistical comparison of length and weight between inner Doubtful Sound fish and those from other sites for year groups 3 , 4, 5 and 6 (Fig. 4). No significant difference in either dimension was detected for fish of the same age class within these year groups ( $p \geq 0.4638$ ). Notolabrus celidotus from inner Doubtful Sound ranged in length and weight from $162 \pm 8(\mathrm{SE}) \mathrm{mm}$ and $66.6 \pm 10.1 \mathrm{~g}$ at

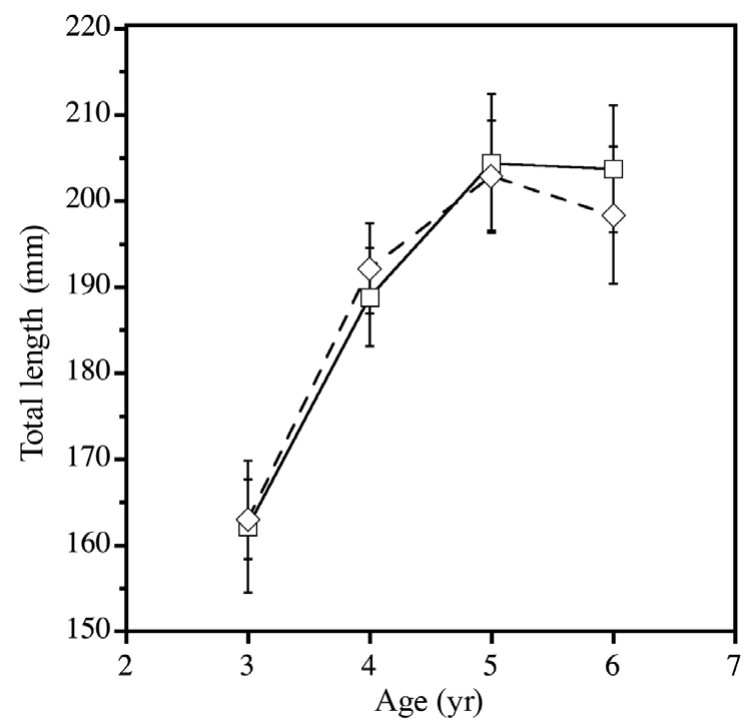

Fig. 4. Notolabrus celidotus. Length at age (mean $\pm 1 \mathrm{SE}$ ) for individuals collected from sites in the inner reaches of Doubtful Sound $(\square)$, and from sites throughout Fiordland $(\diamond)$
Year 3 to $204 \pm 7 \mathrm{~mm}$ and $134.9 \pm 15.2 \mathrm{~g}$ at Year $6 . \mathrm{N}$. celidotus from other sites ranged in length and weight from $163 \pm 5 \mathrm{~mm}$ and $67.2 \pm 5.7 \mathrm{~g}$ at Year 3 to $198 \pm 8$ $\mathrm{mm}$ and $126.9 \pm 16.9 \mathrm{~g}$ at Year 6. N. celidotus reached $\mathrm{L}_{\infty}$ at $5 \mathrm{yr}$ of age. No Year 1 fish were observed, and there were too few samples of Year 2 fish to justify statistical comparison among sites.

\section{DISCUSSION}

The results of this study indicate that the composition of basal carbon source pools supporting shallow water benthic communities in the inner reaches of Doubtful Sound is different from that supporting other similar communities distributed throughout Fiordland. In inner Doubtful Sound, chemosynthetically fixed organic matter forms a higher proportion of the diet of the macroinfaunal community upon which the common wrasse Notolabrus celidotus feeds. $\delta^{13} \mathrm{C}, \delta^{15} \mathrm{~N}$, $\delta^{34} \mathrm{~S}$ and analysis of essential fatty acids from muscle tissues of $N$. celidotus provide discriminators of the carbon source pools supporting the prey base. In Doubtful Sound, where the abundance of filter-feeding bivalves has declined due to an altered salinity environment, organic matter of marine origin is fuelling a lower proportion of secondary production than at reference sites. While we hypothesized that this shift to more recycled organic matter sources would affect the growth of $N$. celidotus, there was no evidence that age at size was different among sites.

The stable isotope ratios of an animal's tissues integrate diet over longer periods than stomach contents, enabling estimation of the proportional use of sources of organic matter by the consumer (Cocheret de la Morinière et al. 2003, Connolly et al. 2005). Stable isotope ratios of carbon and nitrogen were lower in fish from inner Doubtful Sound relative to fish sampled from all other inner fjord sites throughout Fiordland, consistent with a ${ }^{13} \mathrm{C}$ - and ${ }^{15} \mathrm{~N}$-depleted source of organic matter such as forest litter or the common bivalve Solemya parkinsonii, which has a symbiotic relationship with chemoautotrophic bacteria. While these sources for Notolabrus celidotus were not discriminated using $\delta^{13} \mathrm{C}$ or $\delta^{15} \mathrm{~N}$, large differences in values of $\delta^{34} \mathrm{~S}$ provided robust discrimination between forest litter and chemoautotrophs. The mixing model based on $\delta^{13} \mathrm{C}$ and $\delta^{34} \mathrm{~S}$ estimated that while forest litter was not a direct source of organic matter for the fish, S. parkinsonii or other sources of sulfur-oxidising bacteria comprised 21 to $33 \%$ (95\% CI) of the diet of N. celidotus from inner Doubtful Sound, and also likely contributed to the diet of this species at other sites. N. celidotus from Bradshaw Sound had values of $\delta^{34} \mathrm{~S}$ that were intermediate between those from inner Doubtful 
Sound and Dusky Sound, suggesting that a ${ }^{34}$ Sdepleted source such as chemoautotrophic bacteria or forest litter contributed to diet at this site. However, when considered in combination with fatty acid data, we conclude that the highest proportional incorporation of chemoautotrophic bacteria occurs at sites in inner Doubtful Sound. Repeated isotopic analysis of $N$. celidotus sampled from inner Doubtful Sound sites over a period of 3 yr shows that chemoautotrophic bacteria are a consistent feature in the carbon sources to $N$. celidotus in this fjord. Stomach content analyses for $N$. celidotus are not reported here, but previous analyses of its diet indicated that it feeds on a wide range of macroinvertebrates (Jiang 2002, McLeod 2008).

While stable isotopes are a powerful tool for elucidating organic matter pathways in food webs, estimates of diet made by stable isotope mixing models are vulnerable to assumptions about the trophic level at which a consumer is feeding, and the amount of isotopic fractionation occurring per trophic level in food webs. As these parameters have not been experimentally resolved for Notolabrus celidotus or for the underlying food web, we employed a complementary method to trace organic matter flux, namely the $\delta^{13} \mathrm{C}$ values of specific fatty acids. Fatty acids that are transferred from primary producers to consumers can provide biomarkers for this source, providing that they are not also biosynthesized by the consumer from other lipid compounds. The ability to obtain $\delta^{13} \mathrm{C}$ measurements of these compounds allows this requirement to be confirmed. Although cis-vaccenic acid (18:107c) can be biosynthesized by many fauna, it is also sourced from bacteria (McLeod \& Wing 2007, 2009, Jack et al. 2009), and $\delta^{13} \mathrm{C}$ of $\sim-33 \%$ or for $18: 1$ (of which $18: 1 \omega 7 \mathrm{C}$ was a key component) from $N$. celidotus from inner Doubtful Sound provides an indication that these bacteria are likely chemoautotrophic. At other sites, slightly more positive values of $\delta^{13} \mathrm{C}$ for 18:1 suggests that this compound likely represents a mix of heterotrophic and chemoautotrophic bacteria particularly at Bradshaw Sound; lower abundances of 18:1 $107 \mathrm{C}$ for fish from Chalky and Dusky Sounds indicate that this bacterial source forms a smaller dietary component than at inner Doubtful Sound. These conclusions were supported by values of $\delta^{34} \mathrm{~S}$. The values of $\delta^{13} \mathrm{C}$ for $18: 1$ fatty acids from fish collected in inner Doubtful Sound are consistent with a decomposed forest litter source of carbon $\left(\mathrm{CO}_{2[\mathrm{aq}]}\right)$ being fixed by chemoautotrophic bacteria (Scott et al. 2004, McLeod \& Wing 2007, 2009). In this case, the compound specific isotopic analysis of lipids provides an independent test of differences in carbon source pools supporting $N$. celidotus at altered and unaltered habitats.

While the findings of this study are consistent with other studies of the food web in the region, the degree of generality in the feeding behaviour of Notolabrus celidotus may influence the patterns observed. Local observations of foraging behaviour indicate that this species feeds primarily on small epibenthic, and shallow-burrowing invertebrates, which may lead to a discrimination against larger and deep-burrowing fauna. As the 3 main invertebrates responsible for uptake of forest litter carbon (the urchin Echinocardium cordatum, the polychaete Pectinaria australis, and the clam Solemya parkinsonii; McLeod \& Wing 2009) are all of relatively large body size, and/or are deep-burrowing, it is possible that the relative use of forest litter by the communities as a whole has been underrepresented in the tissues of $N$. celidotus. However, as we are making comparisons among sites using the same species, such discrimination is unlikely to affect the usefulness of $N$. celidotus to detect differences in community-level carbon flux among sites that differ in degree of anthropogenic modification. To test whether the observed shift in carbon sources affected the growth of $N$. celidotus, we measured annual growth rings on otoliths, and compared total weight and length for different size classes of fish from altered and unaltered sites. We did not detect differences in age at size among sites. $N$. celidotus are protogynous hermaphrodites, with a terminal male phase (Jones 1980). We hypothesize that if diet influences the growth of this species, the effect would be with respect to $K$ (the rate of approach to the asymptotic length $\mathrm{L}_{\infty}$ in the von Bertalanffy growth function); hence, we would most likely see differences in younger fish. Unfortunately, the small sample sizes for 1 and 2 yr old fish did not provide sufficient power to test for differences.

Possible drivers of the shift in carbon source supporting communities in inner Doubtful Sound could include (1) reduced representation of filter-feeding bivalves in communities at modified sites changing the routing of organic matter, (2) the altered physical environment (salinity/flow) leading to a reduction in marine algal productivity in inner Doubtful Sound, or (3) a combination of these drivers. As we do not have comparative measurements of macroalgae and phytoplankton abundance throughout the study sites, we cannot determine which of these scenarios is most likely. However, our results confirm that the freshwater outflow from the power station has induced a shift in the basal sources of organic matter supporting the shallow estuarine communities in the inner reaches of Doubtful Sound. An alternative explanation for the patterns observed could be altered feeding behavior of Notolabrus celidotus in inner Doubtful Sound. While we are unable to tease apart the relative influence of potential behavioral changes and altered infaunal community composition, we believe the latter provides the most parsimonious explanation for the observed 
patterns in stable isotope ratios. In conclusion, this study has demonstrated that differences in the composition of organic matter sources for a community can be detected in the chemical composition of tissues from a common generalist-feeding fish.

Acknowledgements. We thank K. Rodgers, N. Beer, P. Meredith, the crew of the RV 'Southern Winds' (Department of Conservation), Isotrace NZ Ltd., and P. Nichols and A. Revill (CSIRO, Hobart, Australia). Comments from 2 anonymous reviewers were much appreciated. This research was supported by a Marsden Grant (to S.R.W., Royal Society), a Bright Futures Top Achiever Doctoral Scholarship (R.J.M.), the Todd Foundation (R.J.M.), a William Georgetti Scholarship (R.J.M.), and the Departments of Marine Science and Chemistry, University of Otago. This research was conducted under a University of Otago Animal Ethics Permit (ET 13/08).

\section{LITERATURE CITED}

Bligh EG, Dyer WJ (1959) A rapid method of total lipid extraction and purification. Can J Biochem Physiol 37:911-917

Campana SE (2001) Accuracy, precision and quality control in age determination, including a review of the use and abuse of age validation methods. J Fish Biol 59:197-242

> Cocheret de la Morinière E, Pollux BJA, Nagelkerken I, Hemminga MA, Huiskes AHL, van der Velde G (2003) Ontogenetic dietary changes of coral reef fishes in the mangroveseagrass-reef continuum: stable isotopes and gut-content analysis. Mar Ecol Prog Ser 246:279-289

Cole JJ, Carpenter SR, Pace ML, Van de Bogert MC, Kitchell JF, Hodgson JR (2006) Differential support of lake food webs by three types of terrestrial organic carbon. Ecol Lett 9:558-568

Connolly RM, Hindell JS, Gorman D (2005) Seagrass and epiphytic algae support nutrition of a fisheries species, Sillago schomburgkii, in adjacent intertidal habitats. Mar Ecol Prog Ser 286:69-79

Dalsgaard J, St. John M, Kattner G, Müller-Navarra D, Hagen W (2003) Fatty acid trophic markers in the pelagic marine environment. Adv Mar Biol 46:225-340

> Darnaude AM, Salen-Picard C, Harmelin-Vivien ML (2004) Depth variation in terrestrial particulate organic matter exploitation by marine coastal benthic communities off the Rhone River delta (NW Mediterranean). Mar Ecol Prog Ser 275:47-57

Gibbs MT, Bowman MJ, Dietrich DE (2000) Maintenance of the near-surface stratification in Doubtful Sound, a New Zealand fjord. Estuar Coast Shelf Sci 51:683-704

Guelinckx J, Maes J, Van Den Driessche P, Geysen B, Dehairs $\mathrm{F}$, Ollevier $\mathrm{F}$ (2007) Changes in $\delta^{13} \mathrm{C}$ and $\delta^{15} \mathrm{~N}$ in different tissues of juvenile sand goby Pomatoschistus minutus: a laboratory diet-switch experiment. Mar Ecol Prog Ser 341: 205-215

- Harding JS, Hawke DJ, Holdaway RN, Winterbourn MJ (2004) Incorporation of marine-derived nutrients from petrel breeding colonies into stream food webs. Freshw Biol 49:576-586

> Hocking MD, Reimchen TE (2009) Salmon species, density and watershed size predict magnitude of marine enrichment in riparian food webs. Oikos 118:1307-1318

> Jack L, Wing SR, McLeod RJ (2009) Prey base shifts in the rock lobster Jasus edwardsii in response to habitat conversion in Fiordland marine reserves: implications for effec- tive spatial management. Mar Ecol Prog Ser 381:213-222 Jiang W (2002) Age, growth and feeding ecology of five cooccurring fishes in southern New Zealand. PhD thesis, University of Otago, Dunedin

Johns RB, Nichols PD, Perry GJ (1979) Fatty acid composition of ten marine algae from Australian waters. Phytochemistry 18:799-802

Jones GP (1980) Growth and reproduction in the protogynous hermaphrodite Pseudolabrus celidotus (Pisces: Labridae) in New Zealand. Copeia 1980:660-675

- Kharlamenko VI, Kiyashko SI, Imbs AB, Vyshkvartzev DI (2001) Identification of food sources of invertebrates from the seagrass Zostera marina community using carbon and sulfur stable isotope ratio and fatty acid analyses. Mar Ecol Prog Ser 220:103-117

> McCutchan JH Jr, Lewis WM Jr, Kendall C, McGrath CC (2003) Variation in trophic shift for stable isotope ratios of carbon, nitrogen, and sulfur. Oikos 102:378-390

McLeod RJ (2008) The roles of key species and functional guilds in facilitating fluxes of organic matter across habitat boundaries in Fiordland. PhD thesis, University of Otago, Dunedin

> McLeod RJ, Wing SR (2007) Hagfish in the New Zealand fjords are supported by chemoautotrophy of forest carbon. Ecology 88:809-816

McLeod RJ, Wing SR (2008) Influence of an altered salinity regime on the population structure of two infaunal bivalve species. Estuar Coast Shelf Sci 78:529-540

> McLeod RJ, Wing SR (2009) Strong pathways for incorporation of forest litter into a benthic marine food web. Estuar Coast Shelf Sci 82:645-653

Nelson WA, Villouta E, Neill KF, Williams GC, Adams NM, Slivsgaard R (2002) Marine macroalgae of Fiordland, New Zealand. Tuhinga 13:117-152

Peterson BJ, Howarth RW (1987) Sulfur, carbon, and nitrogen isotopes used to trace organic matter flow in the saltmarsh estuaries of Sapelo Island, Georgia. Limnol Oceanogr 32:1195-1213

> Peterson BJ, Howarth RW, Garritt RH (1985) Multiple stable isotopes used to trace the flow of organic matter in estuarine food webs. Science 227:1361-1363

Phillips DL, Gregg JW (2001a) Uncertainty in source partitioning using stable isotopes. Oecologia 127:171-179

Phillips DL, Gregg JW (2001b) Erratum: uncertainty in source partitioning using stable isotopes. Oecologia 128:304

Pickrill RA (1980) Beach and nearshore morphology and sedimentation in Fiordland, New Zealand: a comparison between fiords and glacial lakes. NZ J Geol Geophys 23: 469-480

Pickrill RA (1987) Circulation and sedimentation of suspended particulate matter in New Zealand fjords. Mar Geol 74:21-39

Polis GA, Hurd SD (1996) Linking marine and terrestrial food webs: allochthonous input from the ocean supports high secondary productivity on small islands and coastal land communities. Am Nat 147:396-423

> Rodgers KL, Wing SR (2008) Spatial structure and movement of blue cod Parapercis colias in Doubtful Sound, New Zealand, inferred from $\delta^{13} \mathrm{C}$ and $\delta^{15} \mathrm{~N}$. Mar Ecol Prog Ser 359:239-248

> Rounick JS, Winterbourn MJ, Lyon GL (1982) Differential utilization of allochthonous and autochthonous inputs by aquatic invertebrates in some New Zealand streams: a stable carbon isotope study. Oikos 39:191-198

Rutger SM, Wing SR (2006) Effects of freshwater input on shallow-water infaunal communities in Doubtful Sound, New Zealand. Mar Ecol Prog Ser 314:35-47 
Scott KM, Schwedock J, Schrag DP, Cavanaugh CM (2004) Influence of form IA RubisCO and environmental dissolved inorganic carbon on the $\delta^{13} \mathrm{C}$ of the clam-chemoautotroph symbiosis Solemya velum. Environ Microbiol 6:1210-1219

Suring E, Wing SR (2009) Isotopic turnover rate and fractionation in multiple tissues of red rock lobster (Jasus edwardsii) and blue cod (Parapercis colias): consequences for ecological studies. J Exp Mar Biol Ecol 370:56-63

Tallis HM, Wing SR, Frew RD (2004) Historical evidence for

Editorial responsibility: Peter Steinberg,

Sydney, New South Wales, Australia habitat conversion and local population decline in a New Zealand fjord. Ecol Appl 14:546-554

Vander Zanden MJ, Vadeboncoeuri Y (2002) Fishes as integrators of benthic and pelagic food webs in lakes. Ecology 83:2152-2161

- Wing SR, McLeod RJ, Clark KL, Frew RD (2008) Plasticity in the diet of two echinoderm species across an ecotone: microbial recycling of forest litter and bottom-up forcing of population structure. Mar Ecol Prog Ser 360:115-123

Submitted: January 7, 2010; Accepted: May 22, 2010

Proofs received from author(s): July 22, 2010 